УДК 57.086.16

\author{
I. О. Тіханков
}

Дніпропетровський національний університет ім. Олеся Гончара

\title{
ПЕРСПЕКТИВИ ВИКОРИСТАННЯ НІТРАТУ КОБАЛЬТУ ЯК КОНТРАСТЕРУ ДЛЯ ЕЛЕКТРОННОЇ МІКРОСКОПІЇ БІОЛОГІЧНИХ ОБ'ЄКТІВ
}

\begin{abstract}
Розроблено методику контрастування ультратонких зрізів рослинних і тваринних тканин, залитих в епоксидні смоли, водними розчинами нітрату кобальту. Розглянуто різні аспекти такої підготовки препаратів. Визначено оптимальні умови проведення контрастування зрізів. Проаналізовано переваги розробленої методики порівняно із загально прийнятим способом підготовки препаратів. Оцінено перспективи її використання при вивченні морфології та гістохімії різноманітних біологічних об'єктів.
\end{abstract}

I. O. Tikhankov

Oles' Gonchar Dnipropetrovsk National University

\section{PROSPECTS OF USE OF COBALT NITRATE AS A CONTRAST MEDIUM IN ELECTRON MICROSCOPY OF BIOLOGICAL SAMPLES}

The method of cobalt nitrate impregnation of ultrathin sections of plant and animal tissues, which are embedded in epoxy resin, has been worked out. Various aspects of such handling of specimens have been examined. Best conditions for the sections staining were determined. The advantage of this method was analyzed. The estimation of the possibilities to implicate this method for the morphological and histochemical study of various biological specimens has been made.

\section{Вступ}

Формування зображення будь-яких об'єктів на екрані електронного мікроскопа залежить від їх здатності розсіювати потік електронів, які мають певну енергію. Біологічні об’єкти самі по собі не можуть відхилити електрони, що швидко рухаються, від їх початкової траєкторії, оскільки складаються з атомів легких елементів. Щоб можна було побачити структуру тканин і клітин, їм необхідно у штучний спосіб надати здатність поглинати або розсіювати електрони. Зазвичай це робиться обробкою відібраного матеріалу солями важких металів на різних стадіях підготовки об'єкта $[1 ; 7 ; 14]$. Важкі метали зв'язуються з біологічними структурами; це робить тканини достатньо щільними, аби вони змогли відхилити електрони та сформувати зображення.

Перший етап такої обробки відбувається під час постфіксації: частіше розчинами тетроксиду осмію $\mathrm{OsO}_{4}$, рідше - перманганату калію $\mathrm{KMnO}_{4}$ [9]. Але в обох випадках контраст не є достатнім, особливо якщо необхідно розганяти електрони напругою в 100-120 кВ. Тому проводять імпрегнацію тканин на ультратонких зрізах, які вже змонтовані на сіточках або блендах, занурюючи їх у водні та спиртові розчини з солями важких металів. Для цього використовують солі вольфраму, хрому, свинцю тощо. Найпоширенішою є методика контрастування за E. S. Reynolds [10; 12]. Вона дає сильний контраст і стабільні результати абсолютно для всіх біологічних об'єктів. Іноді хімічну 
обробку супроводжують опроміненням мікрохвилями [8; 11]. Однак тотальне контрастування потрібне не в усіх випадках. Зокрема, при проведенні цитохімічних досліджень необхідно, щоб достатньо чітко було помітно структуру об'єкта і при цьому вона не маскувала електронно щільні мітки, які виявляють місця локалізації ферментів чи конкретних білків $[3 ; 4 ; 6 ; 13 ; 15]$. Для цього контраст має бути помірним. Регулювати його, зменшуючи час обробки цитратом свинцю за Рейнольдом, проблематично, оскільки той зв'язується з білками інтенсивно, і досягти стабільних результатів у такий спосіб неможливо. Існує ще один аспект. Він полягає у тому, що цитрат свинцю необхідно синтезувати. Практика показує, що далеко не кожний синтез проходить вдало. Переважно причиною невдачі стає недостатня кваліфікація дослідника, однак до цього можуть призвести й неякісні хімікати. Крім того, гідроксид натрію, присутній у розчині, активно поглинає вуглекислий газ повітря, утворюючи карбонат. Будь-який контакт із синтетичними матеріалами (накінечник автоматичної піпетки і т. п.) призводить до часткової абсорбції цитрату. Усі ці причини більшою чи меншою мірою змінюють хімічний склад розчину, що абсолютно неприпустимо, бо веде до повної відсутності контрасту.

Мета роботи полягала в розробці альтернативної методики контрастування епонаралдитових зрізів, яка була б простішою у використанні порівняно зі стандартною [10] i, разом із тим, давала б стабільні результати. Ця стаття - результат багаторічної роботи автора у різних електронномікроскопічних лабораторіях. У ній робиться підсумок власного досвіду використання неорганічних сполук для контрастування біологічних об'єктів. Увагу в ній приділено нітрату кобальту як речовині, що дає надійні та стабільні результати і може застосовуватися при постановці найрізноманітніших дослідів із використанням трансмісійної електронної мікроскопії.

\section{Матеріал і методи досліджень}

Об’єкти досліджень - вегетативні та генеративні органи кукурудзи (Zea mays L.), центральна нервова система щурів (лінії Вістар), різні тканини бджоли медоносної (Apis mellifera L.). Увесь рослинний матеріал фіксували 4 \% глутаровим альдегідом на $0,12 \mathrm{M} K$-Na-фосфатному буфері при $+4 \ldots+6^{\circ} \mathrm{C}$ протягом 24-36 годин. Для тваринного матеріалу використовували $4 \%$ формальдегід, який готували з параформу [1]. Умови проведення фіксації були аналогічними, за винятком тривалості, яка у разі відбору мозкових тканин щурів могла збільшуватися до 3 діб. Постфіксацію проводили $1 \% \mathrm{OsO}_{4}$ на тому самому буфері протягом двох годин при $+4 \ldots+6^{\circ} \mathrm{C}$. Схеми проведення матеріалу через етанол $\mathrm{i}$ ацетон, насичування епоксидними смолами варіювали залежно від типу тканин і розмірів відібраних шматочків $[1 ; 3]$. Заливку проводили в епон, свіжу суміш якого готували безпосередньо перед використанням за наступним прописом: Epon 812 - 7,8 мл, Epon DDSA - 5,6 мл, Epon MNA - 4,6 мл, Epon DMP-30 3 краплини.

Ультратонкі зрізи робили на ультрамікротомах серії УМТП і монтували на паладовані сіточки. Для контрастування використовували водні розчини $\mathrm{Co}\left(\mathrm{NO}_{3}\right)_{2}$ наступних концентрацій: $10,20,30,40,50 \%$. Обробку проводили за температури $+20,+25,+30$, $+40^{\circ} \mathrm{C}$. Ї̈ тривалість варіювали в межах від 5 до 90 хвилин. Після того зрізи вивчали на мікроскопах TESLA BS-613, ЭМВ-100Л, ЕМ-125 при напрузі розгону 50, 75 та 100 кВ.

\section{Результати та їх обговорення}

Оптимальні результати для тотального контрастування дають 20 і 30 \% розчини. За менших концентрацій контраст слабший. Застосування вищих концентрацій жодних переваг не дає. Температура розчину не збільшує контрастності, проте може спричи- 
нити появу артефактів. Тривалість обробки з метою отримання найбільшого контрасту може коливатися в межах $15-40$ хвилин за температури $+20 \ldots+23^{\circ} \mathrm{C}$ без небезпеки виникнення артефактів.

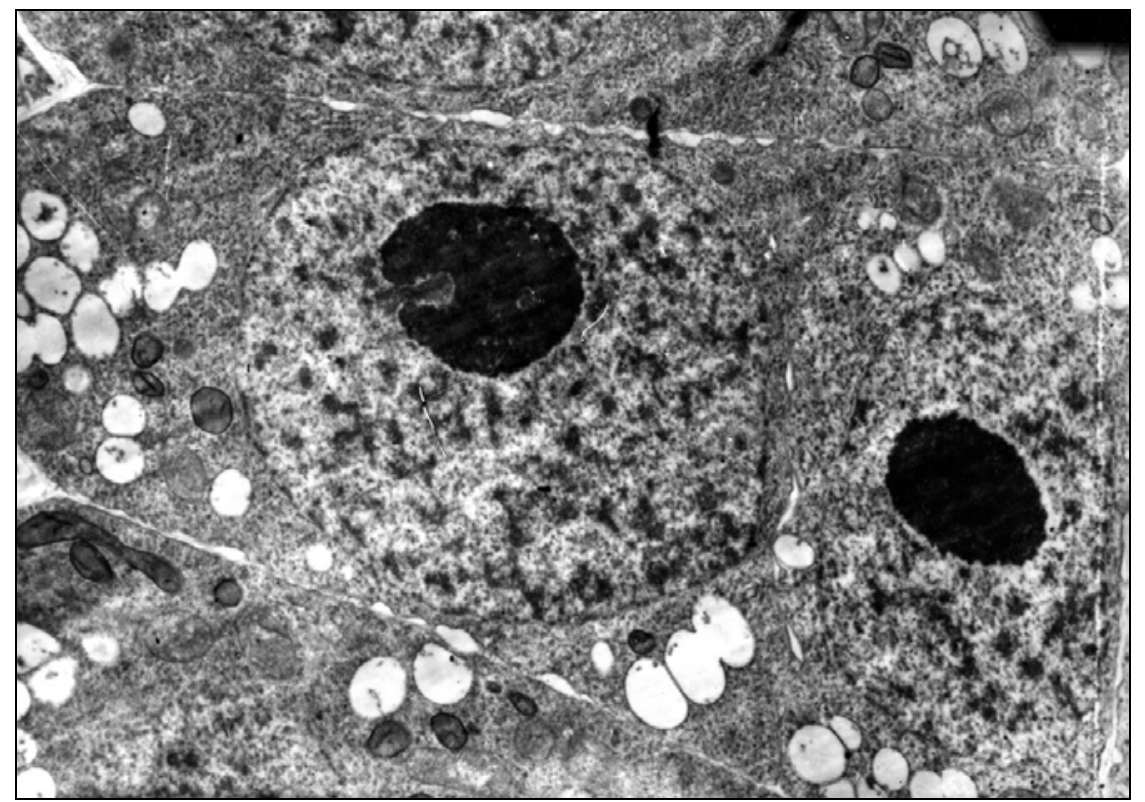

Рис. 1. Завершальна стадія формування тапетуму пильника кукурудзи (50 кB, х 4500)

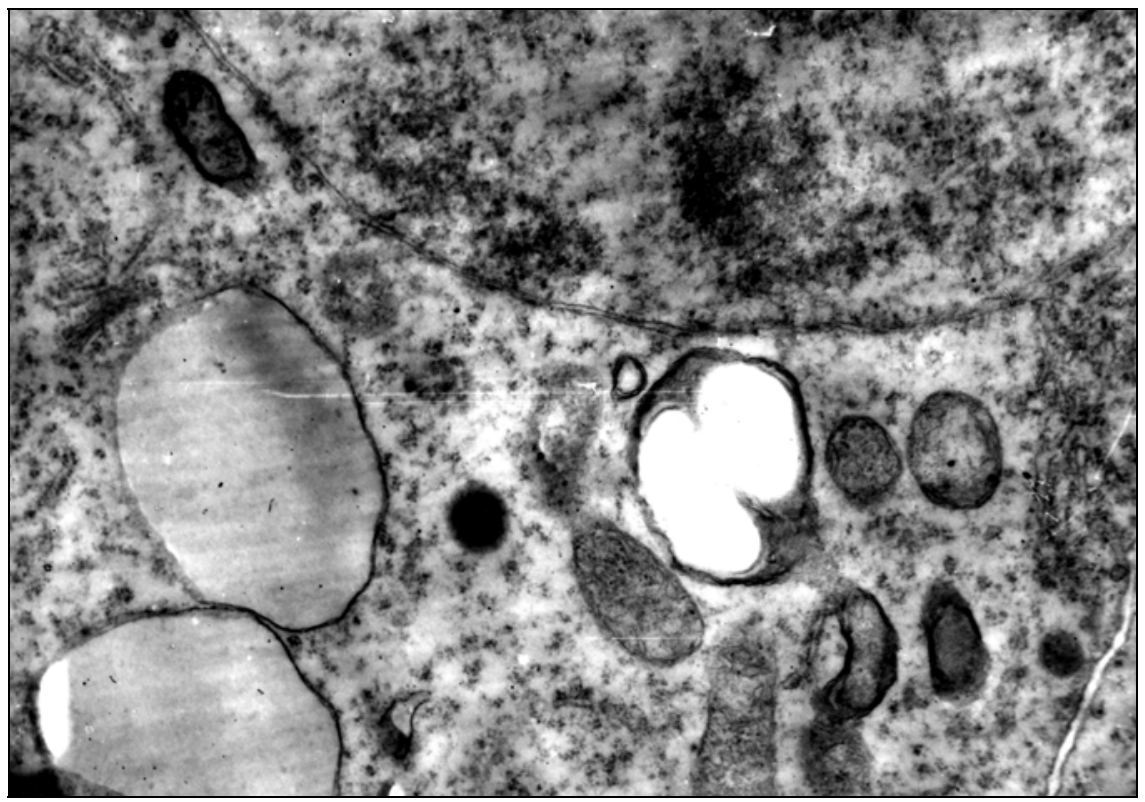

Рис. 2. Ендотецій кукурудзи (75 кВ, х 1800)

Найсильніший контраст отриманий на рослинних об'єктах. Усі типи тканин однаково добре зв'язували $\mathrm{Co}\left(\mathrm{NO}_{3}\right)_{2}$. На електронограмах чітко помітно всі мембранні структури, рибосоми, крохмальні зерна, пластоглобули, клітинні стінки (рис. 1-3). Зображення однаково якісне при всіх величинах напруги розгону. Добре контрастувався цитозоль, що дає змогу оцінити його тонку структуру та густину. Для досягнення найбільшої електронної густини матеріалу достатньо було обробки зрізів протягом 
20 хвилин у $20 \%$ розчині за температури $+20^{\circ} \mathrm{C}$. Триваліша обробка (до 60 хвилин) не посилювала контрасту. Більше того, починаючи з 50 хвилин з'являється небезпека виникнення артефактів у вигляді дрібнозернистого осаду. Підвищення температури на величину понад $+10^{\circ} \mathrm{C}$ також спричиняло появу осаду, а контрасту не посилювало. Грубіший осад присутній на зрізах у разі 20 -хвилинної обробки при $+40^{\circ} \mathrm{C}$.

Таким чином, можна зробити висновок, що $\mathrm{Co}\left(\mathrm{NO}_{3}\right)_{2}$ добре зв'язується з більшістю сполук, характерних для рослинних тканин. Але не всі клітинні структури зв'язують його однаковою мірою. Однією з переваг такого способу контрастування є те, в що меристемах і етіольованих тканинах мембранна оболонка пропластид абсорбує більшу кількість $\mathrm{Co}\left(\mathrm{NO}_{3}\right)_{2}$, ніж мембрани мітохондрій (тому вони виглядають на електронограмах значно темнішими). При звичайному контрастуванні відрізнити мітохондрії від пропластид часто неможливо, оскільки вони у згаданих тканинах не мають крист і пластоглобул, а солі свинцю зв’язують так само, як мембрани пластид.

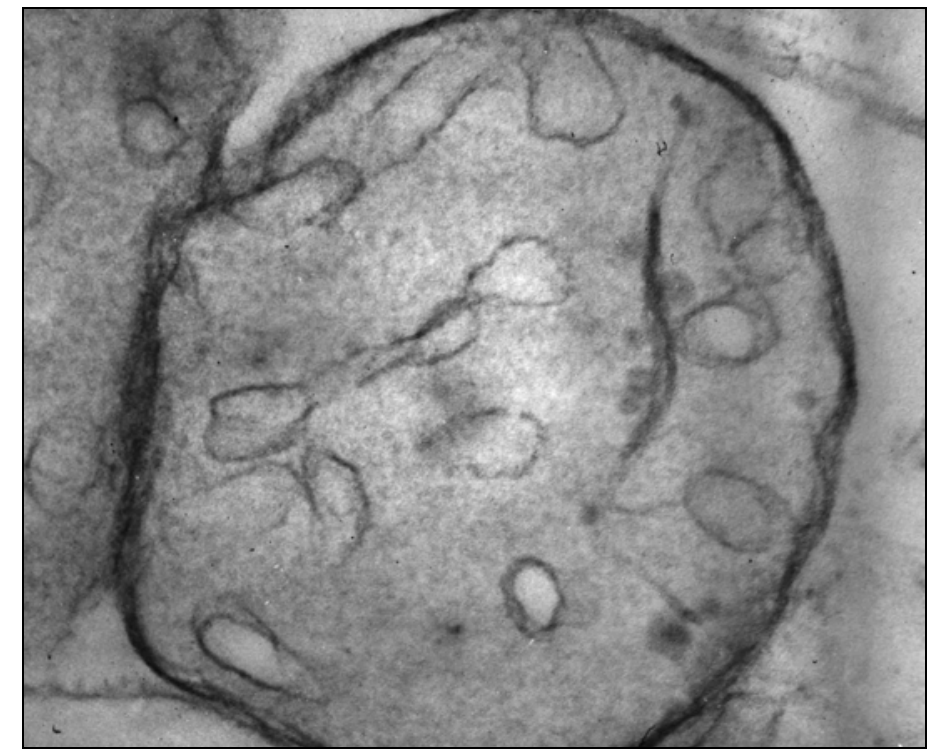

Рис. 3. Мітохондрія сильно диференційованих клітин кукурудзи, мало активних у плані біосинтезу (100 кВ, х 68000)

Дуже інтенсивно, краще, ніж при обробці за E. S. Reynolds [10], контрастер накопичується у рибосомах, що полегшує аналіз цих структур, особливо якщо вони не пов'язані з ендоплазматичним ретикулумом. Пластоглобули та ліпідні краплини контрастуються менш інтенсивно порівняно зі звичайною методикою. Обробка $\mathrm{Co}\left(\mathrm{NO}_{3}\right)_{2}$ дозволяє вивчати тонку структуру ядерок за великих збільшень. У них чітко розрізняються центральна зона, кортикальний шар. Мембранні структури, за винятком пропластид, мають дещо слабший контраст, ніж після обробки цитратом свинцю. Однак ця різниця незначна і не знижує інформаційності електронограм. Таким чином, можна констатувати, що застосування $\mathrm{Co}\left(\mathrm{NO}_{3}\right)_{2}$ для контрастування об'єктів рослинного походження на епонових зрізах замість стандартної методики дає не гірші результати, а в окремих моментах може бути навіть більш бажаним.

Дещо інша картина спостерігається при вивченні ультраструктури тваринних тканин. Такі об'єкти абсорбують $\mathrm{Co}\left(\mathrm{NO}_{3}\right)_{2}$ менш інтенсивно. Тому отримати зображення з потрібним контрастом можна лише за рахунок максимального зменшення діафрагми об'єктивної лінзи. Триваліша обробка розчинами $\mathrm{Co}\left(\mathrm{NO}_{3}\right)_{2}$, підвищення їх концентрації або температури контрасту не посилюють, а призводять до виникнення арте168 
фактів. На відміну від зрізів із рослинного матеріалу, зерна осаду стають значно більшими та набирають округлої форми (рис. 6). Хоча контраст мембранних структур слабший за той, що має місце у разі рослинних об'єктів, він достатній для детального вивчення ультраструктури (рис. 4-6).

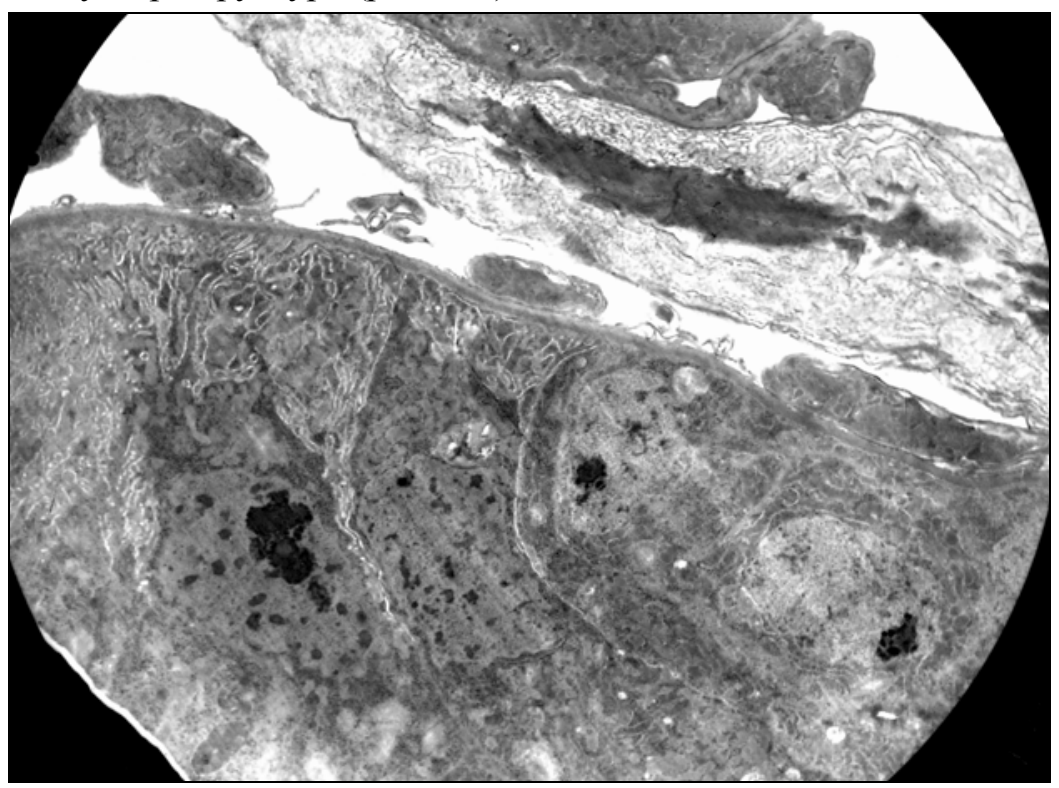

Рис. 4. Середня кишка бджоли з м'язами (70 кВ, х 4000)

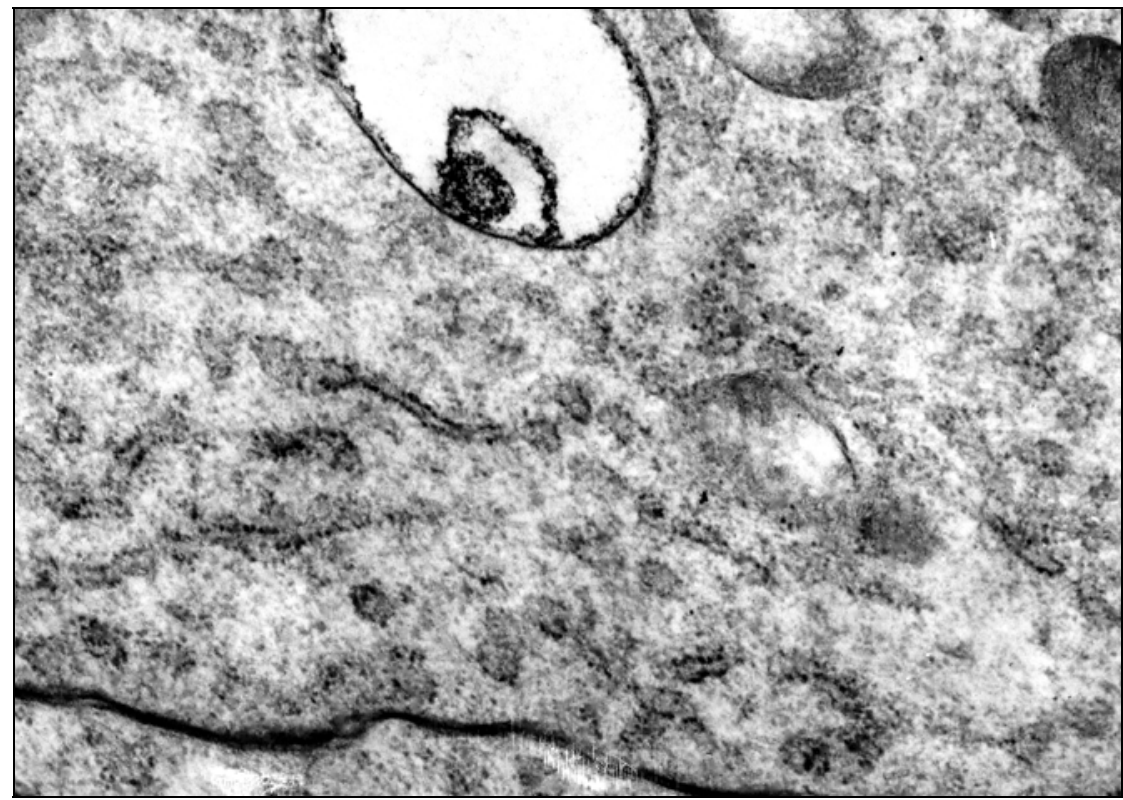

Рис. 5. Ультраструктура клітин середньої кишки бджоли (100 кВ, х 30000)

Найслабший контраст спостерігався при вивченні різних відділів головного мозку щурів, зокрема мозочка, таламуса та кори мозку. Він був абсолютно недостатнім для самостійного використання нітрату кобальту як контрастера.

Існує ще один аспект цього питання, пов'язаний із процедурою зневоджування шматочків тканин. На його завершальних стадіях прийнято замінювати етанол на аце- 
тон. Однак у випадку із тваринними об’єктами цей етап можна пропустити, оскільки такі тканини значно легше за рослинні просочуються етанолом і розчиненим у ньому епоном. Крім того, виключення ацетону запобігає вимиванню ліпідів, що дозволяє більшою мірою зберегти нативність клітинних структур. Наслідок цього - зниження контрасту за умов обробки зрізів нітратом кобальту. Це відбувається за рахунок зниження адсорбції іонів важкого металу мембранами, а також через зростання електронної густини заливочного середовища. Причому друга складова переважає. Ї̈̈ можна виключити у разі використання доочищеного етанолу, а не того, що надходить у продаж. Це свідчить про наявність в останньому домішок, які небажаним чином впливають на полімеризацію епонової суміші. Крім того, такі блоки важко ріжуться на ультрамікротомі. Проведення зразків тваринного матеріалу на заключних етапах зневоджування через ацетон у будь-якому разі підвищує контраст.

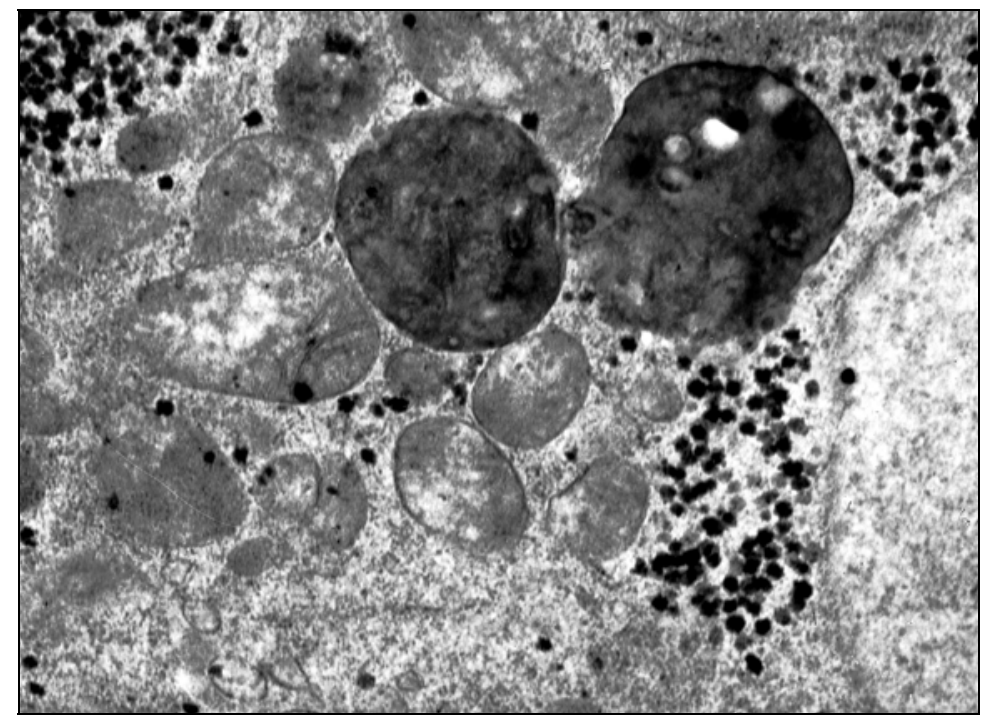

Рис. 6. Артефакти у вигляді численних темних гранул, які виникають при переконтрастуванні нітратом кобальту

Аналізуючи результати контрастування різних типів об'єктів, можна дійти висновку, що контраст буде тим кращий, чим менший вміст ліпідів у тканинах. Імовірно, що солі кобальту активно абсорбуються білками і не так інтенсивно зв'язуються ліпідними сполуками. Виняток можуть становити фосфоліпіди. Наявність у них полярних груп робить молекули фосфоліпідів здатними взаємодіяти з водними розчинами електролітів [2]. На цьому засноване використання нітрату кобальту як фіксатора в деяких методиках [5]. Відомо також, що тканини рослин вміщують меншу кількість ліпідів, ніж тваринні. Найбільшим умістом ліпідів, зокрема сфінгомієлінів, характеризуються нервові тканини, імовірно тому для них контраст був найнижчим. Обробка відібраних зразків ацетоном призводить до більшого вимивання ліпідів і зростання питомого вмісту білків. Тому контраст тваринних об'єктів (за винятком нервової тканини), оброблених у такий спосіб, більший, ніж у разі виключення ацетону з проведення, та дорівнює результатам, які мають місце для рослинних зразків.

\section{Висновки}

Нітрат кобальту може використовуватися для тотального контрастування рослинних об'єктів і повністю замінити стандартну методику обробки зрізів. Для тотального контрастування тваринних тканин, які не вміщують значної кількості ліпідів, 
обов'язковим є проведення відібраних шматочків через ацетон. Для контрастування нервових тканин нітрат кобальту непридатний. Варіювання тривалості обробки зрізів і концентрації застосованого розчину дає змогу в широких межах змінювати ступінь контрастності тканин, що важливо при проведенні цитохімічних досліджень, оскільки не маскуватиме електронно густі мітки в місцях локалізації ферментів і специфічних білків. Небезпека переконтрастування відсутня у широкому діапазоні концентрацій $\mathrm{Co}\left(\mathrm{NO}_{3}\right)_{2}$ і часу обробки ним зрізів. Приготування робочого розчину простіше, ніж стандартна методика. Робочий розчин зберігається триваліший час за кімнатної температури на противагу контрастеру Рейнольдса. Він не поглинає $\mathrm{CO}_{2} 3$ повітря і не втрачає своїх властивостей після контакту з полімерами.

\section{Бібліографічні посилання}

1. Гайер Г. Электронная гистохимия. - М.: Мир, 1974. -488 с.

2. Кучеренко Н. Е. Липиды / Н. Е. Кучеренко, А. Н. Васильев. - К.: Вища школа, 1985. - 247 с.

3. Лойда 3. Гистохимия ферментов / 3. Лойда, Р. Госсрау, Т. Шиблер. - М.: Мир, 1982. - 270 с.

4. Хомутовский О. А. Электронная гистохимия рецепторов клеточных мембран / О. А. Хомутовский, М. Д. Луцик, О. Ф. Передерей. - К.: Наукова думка, 1986. - 168 с.

5. Фрайштат Д. М. Реактивы и препараты для микроскопии. Справочник. - М.: Химия, 1980. $-480 \mathrm{c}$.

6. Bruinenberg P. G. Purification and some properties of malate synthase from the methylotrophic yeast Hansenula polymarpha / P. G. Bruinenberg, M. Blaauw, G. Veenhuis // FEMS Microbiol. Lett. - 1989. - Vol. 61. - P. 11-16.

7. Ultrastructure of unicellular $N_{2}$ fixing cyanobacteria from the tropical north atlantic and subtropical north Pacific oceans / L. I. Falcon, S. Lindvall, K. Bauer et al. // J. Phycology. 2004. - Vol. 40. - P. 1074-1078.

8. Hernandes-Chavarria M. Rapid staining of ultrathin sections using microwave irradiation with heat dissipation / M. Hernandes-Chavarria, M. Vargas-Montero // J. Microscopy. - 2001. Vol. 203. - P. 227-230.

9. Nebesárová J. Elektronová microscopie pro biology / http://www.paru.cas.cz/lem/book/ Podkap/4.2.html - 2001.

10. Nome C. F. Cytological alteration produced by Sweet Potato Mild Speckling Virus / C. F. Nome, I. G. Laguna, S. F. Nome // J. Phytopath. - 2006. - Vol. 154. - P. 504-507.

11. Oglu C. Rapid staining of ultrathin sections with the use of a microwave oven / C. Oglu, Kahveci Sirmali // J. Microscopy. - 1998. - Vol. 192. - P. 212-216.

12. Reynolds E. S. The use of lead citrate at high $p H$ as an electropaque stain in electron microscopy // J. Cell Biol. - 1963. - Vol. 17. - P. 208-212.

13. Immunocytochemical detection and location of the membrane-bound nitrite oxidoreductase in cells of Nitrobacter and Nitrospira / E. Spieck, J. Aamand, S. Bartosch, E. Bock // FEMS Microbiol. Lett. - 1996. - Vol. 139. - P. 71-76.

14. Van Duinen S. G. A staining procedure for melanin in semithin and ultrathin epoxy section / S. G. Van Duinen, D. J. Ruiter, E. Scheffer // Histopathology. - 1983. - Vol. 7. - P. 35-48.

15. Yoshikawa H. Histochemical detection of carbohydrates of Blastocystis hominis / H. Yoshikawa, N. Kuwayama, Y. Enose // J. Eukaryotic Microbiol. - 1995. - Vol. 42. - P. 70-74.

Надійила до редколегії 24.01.2008 